\title{
Pain and its Variants in Dickinson's Poetry in 1862-1865
}

\author{
Jine Wang \\ School of Foreign Languages, Shandong Normal University, China
}

Copyright $@ 2015$ Horizon Research Publishing All rights reserved.

\begin{abstract}
Characterized by personal emotions, Emily Dickinson's poetry has a distinctly inward tendency. The years between 1862 and 1865 are an important period in both Dickinson's life and her literary creation. This period witnesses a drastic increase in Dickinson's poetic creation, and the poet demonstrates a sense of loneliness much stronger and a pain and terror more acute. The pain has to do with the poet's inherent fiber, her frustrations in literary creation and other aspects, including the historical trauma of the American Civil War. In her experience of and reflection on pain, Dickinson gradually accepts its existence, and further transforms it into a source of literary inspiration.
\end{abstract}

Keywords Emily Dickinson, Poetry, Pain, Terror, Trauma

\section{Introduction}

In The Letters of Emily Dickinson, Thomas Johnson puts the letters written between 1862 and 1865 into one special group, and observes that "The most crucial and -- though she could not know it -- historically eventful year in Emily Dickinson's life was 1862" (388). The year of 1862 is indeed a crucial and complicated period for Dickinson, witnessing her failure to be sheltered by the institutional religion, her frustration in her attempt to seek fame in literary publication, her suffering from loneliness in her reflection on nature, life and death, and also her inner turmoil under the influence of the American Civil War. The following four years, 1862-1865, also witness a dramatic proliferation in Dickinson's poetic creation. According to The Complete Poems of Emily Dickinson edited by Thomas H. Johnson, over 800 poems were produced in this period, accounting for nearly one half of the total number of Dickinson's poems. Subjects vary, but "pain," "despair" and "terror" stand out and gradually form the major note, betraying the historical trauma without and the conflicts and struggle within.

Pain and terror in loneliness permeate in Dickinson's reflection on life, death, nature, religion, and poetic creation. Words describing such emotions are ubiquitous in her poetic and epistolary works. In letters, loneliness appears 127 times (including such variants as lonely, lone, loneness, lonelier, lonesome") , anxiety, 33 times (including anxious, anxiously), fear, 152 times (including feared, fearful, fearfully, fearing, fears), and pain, 32 times (including pains, painful). Besides, there are other related words, among which are depression, desolate, melancholy, derealization, estrangement, frustration, anguish, affliction, agony,. According to the Subject Index in The Complete Poems of Emily Dickinson, 16 poems describe "pain" directly, while, according to Sharon Leiter, Dickinson "used the word in no less than 50 poems, and its variants -- agony, despair, grief, hurt, and suffering - countless times" (31). With the note of pain reiterated in more poems of hers, Dickinson has become "an anatomist of pain" ( Leiter 31).

\section{Causes for Pain}

Except for two trips to Boston for her eye treatment in 1864 and 1865, Dickinson lives in reticence and obscurity for most of her lifetime in the Homestead and denies the world her appearance, with loneliness as an important label for her. Viewed from an existential perspective, Dickinson acquires a somber perception of life and death, convinced that life is a lonely journey. Man has social attributes. Though keeping epistolary exchanges with her friends, Dickinson, in her intense seclusion, suffers from a subsequent loneliness. She withdraws in her later years to such an extent that, in many people's eyes, she is morbid: "The impression undoubtedly made on me was that of an excess of tension, and of an abnormal life" (L342b). Dickinson is considered weird in her reticence and even "partly cracked" (Monroe 161). Joseph Lyman lived for some time in the Dickinsons' in the winter of 1846, and thought Emily Dickinson mysterious and elusive. In the letter to his fiancee, Lyman notes that, though fond of Emily Dickinson, the girl is abnormal (Sewall 65). Some critics even label Dickinson with such medical terms as melancholia, phobia and schizophrenia. For one time there even appeared a Dickinson who is neurotic and morbid.

While having been influenced by Emersonian Transcendentalism, Dickinson remains a skeptic as to the relationship between man and nature, and man's estrangement from nature contributes to the source of her sense of loneliness, in which Dickinson discerns man's 
collective sense of loneliness when confronted with nature, commonly accompanied by an ensuing terror for the unknown world.

As a woman, Dickinson gets unidentified in many aspects in the $19^{\text {th }}$-century patriarchal culture in the New England, whether it be family education, social involvement, women's codes of behavior or writing standards. In early 1862, Dickinson wrote to T. W. Higginson, editor of The Atlantic Monthly, for the first time, and enclosed four poems to test the possibility of publication. After several correspondence exchanges, Dickinson gradually accepted the judgment that her poetry is not appropriate for publication: "I smile when you suggest that I delay 'to publish' - that being foreign to my thought, as firmament to Fin" (L265). However, Dickinson is far from what she sounds like.

After an occasional attendance at Church in January 1854, Dickinson was seized with terror and she confided to Susan Gilbert that "there I sat, and sighed, and wondered I was scared so" (L154).

The pain and terror initially originating from her inability to be devoted to the institutional religion later spread into other aspects in Dickinson's life, and intensify with her increasing hesitation, isolation and self-denial. In a letter of 1863, Dickinson mentions that she has to make sure that all the doors and windows are closed when she is home alone, for fear that danger might fall any time. The withdrawal, when reinforced to a certain degree, stands out as symptoms of so-called "agoraphobia." Judging from a feminist perspective, agoraphobia is characteristic of females, mainly related to pressures on women by patriarchal culture, and its victims tend to draw back from the crowd, and meanwhile suffer from the consequent negative emotions, including anxiety, terror and pain.

Lack of institutional religious faith and conventional interpersonal and social interactions brings about a sense of inferiority: "Myself the only Kangaroo among the Beauty" (L268). Realization of her own peculiarity exposed Dickinson to further sense of alienation and estrangement, she "hated her peculiarities and ... longed for a normal life" (Monroe 162). Dickinson declares "My wheel is in the dark" (J10), and she herself is practicing "an unfrequented road" (J10). Writing in isolation and loneliness, Dickinson treats poetry as an outlet for her pain and terror: "I felt a palsy, here - the Verses just relieve" (L265). Poems written from 1862 to 1865 constitute the manifest expression of her inner storm.

In addition, the American Civil War constitutes the most important historical reason for Dickinson's intensifying pain. After the outbreak of the war in April in1861, quite a number of young men, first a couple of students from Amherst College, then more young ones from the town, went to join the Union Army (Bingham 418), and before long, there were news of death coming back to the town. Deaths caused by the war, together with her bereavement of the family members later in her life, start her reflection on the nature of life and escalate her pain on an existential level.

Dickinson's pain evolves in the process of her life: from the early mild melancholy and depression to a stronger loneliness and agony in her later years.

\section{Characterization of Pain}

Pain pervades Dickinson's poetry. The 8-line poem "Pain - has an element of Blank -" (J650) both begins and ends with the word "pain," demonstrating the extension of pain. To Dickinson, pain is an infinite existence without past or future, and keeps evolving into "new periods." The poem conveys the speaker's intended proposal: pain is an inherent part of life and cannot be escaped. Martha Shackford recognizes Dickinson's genius in the depiction of pain in this poem: "for sheer, grim, unrelieved expression of emotional truth there are few passages which can surpass the personal experiences revealed" (94). Dickinson presents the destructive force of pain: it deprives people of the ability to judge and the sense of orientations, and the continuation of pain results in a numbness. Dickinson's poems provide pain with concrete forms. Richard Wilber argues that the poem is "not the rephrasing of something known, but the articulation of one person's intense inward observation" (100).

The notion of "eternal pain" is demonstrated in Poem 967, which equips pain with abilities to "expand" and "contract" at will:

Pain - expands the Time -
Ages coil within
The minute Circumference
Of a Single Brain -
Pain contracts - the Time -
Occupied with Shot
Gamuts of of Eternities
Are as they were not-

Albert Gelpi notes the two concepts in the poem and argues that "the expansion and delimitation are, in a sense, synonymous; the mind holds seemingly impossible quantities, but within its enlarged boundaries" (272). Pain takes a variety of forms in human being's life and, to Dickinson, languor is its escalation:

There is a Languor of the Life

More imminent than Pain -

'Tis Pain's Successor - When the Soul

Has suffered all it can - (J396).

The poem "It knew no Medicine -" (J559) reads more like a dialectic illustration of pain:
It knew no Medicine -
It was not Sickness - then -
Nor any need of Surgery -
And therefore - 'twas not Pain-.

The denial of pain highlights is existence. Pain is so sweeping a force that it destroys all.

Dickinson withdraws from the hustle and bustle without and retreats into the peaceful world of her own. She weaves herself a nest, or, meanwhile, a cocoon, where she is 
sheltered from the outside interference, but also caged in a world of pain and terror in loneliness and even troubled by serious mental problems. Amy Lowell observes that Dickinson's inwardness has gone beyond the normal line and her seclusion renders her so "profoundly lonely"(89) that she is susceptible to illness and death. Meanwhile, Lowell notes Dickinson' preoccupation with death: "She could not take up her life again because there was no life to take. Her thoughts came to be more and more preoccupied with the grave" (89).

Though Dickinson's withdrawal is hard to define, it cannot be denied that she suffers pain from her isolation, and her pain gets constantly reiterated and escalated in her poetry. John Cody draws his conclusion with a psychoanalytical approach that Dickinson's early depression has been accumulating all the way to such a degree that "suicide may seem to be the only appropriate recourse" (296). While admiring Dickinson's idiosyncrasy and brilliancy, Mabel Loomis Todd catches the poet's disappointment with the world and inclination to escape: "She is very brilliant and strong, but became disgusted with society \& declared she would leave it when she was quite young" (qtd. Leyda 377).

In the poem "What if I say I shall not wait!" (J277), the speaker is eager to "burst the fleshly Gate" and "file this Mortal - off" to "wade in Liberty." Weighed down by the loneliness in life, Dickinson desires to let go of this world: "To put this World down, like a Bundle-/ And walk steady, away" (J527). The poem "He scanned it - staggered" (J1062) stages the detailed process of a suicide, in which the man is bringing his life to an end, and, after "His Mind were going blind," he "wandered out of Life":

He scanned it - staggered -
Dropped the Loop
To Past or Period -
Caught helpless at a sense as if
His Mind were going blind -
Groped up, to see if God was there -
Groped backward at Himself
Caressed a Trigger absently
And wandered out of Life.

The scene and description triggers the readers' endless imagination and speculation on Dickinson's authentic experience.

\section{Possible Solution to Pain}

Dickinson holds that "Pain has but one Acquaintance" (J1049 ), and this acquaintance is "death". While commenting on this poem, Inder kher observes that "the pain of existence can be relieved only by death ... suicide seems to be the only solution for man's agonized self" (193). Dickinson herself shows great admiration for death as a way of relief or escape:

If this is 'fading'

Oh let me immediately 'fade'!

\author{
If this is 'dying' \\ Bury me, in such a shroud of red! \\ If this is 'sleep,' \\ On such a night \\ How proud to shut the eye!
}

The Subject Index of The Complete Poems of Emily Dickinson by T. H. Johnson lists only two items (J277 \& J1062) under the entry of "suicide," but David Porter offers a longer list of Dickinson's poems addressing suicide both directly or suggestively (besides J257 mentioned above): "Just lost, when I was saved!" (J160), "At last, to be identified!" (J174), "If I'm lost - now -" (J256), "I breathed enough to take the Trick" (J272), "I read my sentence steadily -" (J412), "I had no Cause to be awake -" (J542), to name only a few. These poems either convey a "suicidal wish" or imagination, or dwell on the delineation of a suicidal process.

As is well known, Dickinson shows a preference for the theme of death in her poetry, some of which characterize death not as a forced result but an active choice so as to achieve peace and relax. The poem " "Tis Dying - I am doing" (J692), in the first 3 stanzas, depicts the setting sun, the dropping dusk and her drowsing feet, while the last stanza confides that the speaker is "doing" the "Dying" fearlessly, betraying a composed manner in her experience, or even a desire for death. No longer a pressing shadow or ominous experience, death becomes an active choice: "One might depart at option/ From enterprise below!” (L54). Suicide transforms death into a peaceful and pleasant departure and leaving. Dickinson demonstrates a keen observation and insightful perception of the dying moments so acute and so vivid that no wonder it's speculated that the actual experience must be the poet's own.

While he argues that Dickinson's letters "do not ... support any theory of Dickinson's propensities to suicide" (Porter 289), David Porter does find and admit that one passage in Dickinson's Letter 399 is a persuasive one to back the theory: "Parting is one of the exactions of a Mortal Life. It is bleak - like Dying, but occurs more times. To escape the former, some invite the last" (289). Dickinson holds death to be inviting to escape the pain brought about partings in life.

Although Concordance to the Letters of Emily Dickinson provides no entry of "suicide" at all in its subject index, David Porter is conservative, to a certain degree, in this judgment of Dickinson's letters. John Cody, for instance, presents 4 more letters to illustrate his belief that there are epistolary evidence on Dickinson's suicidal attempt.

Dickinson, in the letter to her Norcross cousin in late 1872, mentions the pain caused by an ill heart and body, declaring that the ill heart and body make death look "choiceless" (L380), which explicitly brings out her impulse to escape the pain and troubles by ending her life. In May 1877, Dickinson writes to one of her friends Mrs. Jenkins and confides to the latter about the increasing rift between Susan and Austin and also Austin's stubbornly painful insomnia, sighing that "Sorrow is unsafe when it is real sorrow" (L501). The 
underlying reason why sorrow is unsafe, to Dickinson, is that it makes enticing the thought of suicide. In her letter to Austin Dickinson in November 1861, Emily Dickinson elaborates on her loneliness at his absence and declares that "it seemed to me I could pack this little earthly bundle, and bidding the world Goodbye, fly away and away, and never come back again to be so lonely here" (L62). The sense of loneliness caused by separation and the consequent pain of loss has worked itself into a crushing depression, contributing to a sense of tiredness of the worldly existence in the poet, hence making suicide sound a soothing and attractive way out.

The crushing force of loneliness and depression is furthered by constant bereavements in Dickinson's later life. Dickinson writes to Higginson, after the death of the latter's wife, in the fall of 1877, telling about her concern: "Danger is not at first, for then we are unconscious, but in the after slower - Days -" (L522).

Besides the 4 letters, one prose fragment, which is undated among Dickinson's letters, writes as follows:

Tis a dangerous moment for any one when the meaning goes out of things and Life stands straight - and punctual - and yet no content(s) (signal) come(s). Yet such moments are. If we survive them they expand us, if we do not, but that is Death, whose if is everlasting. (PF.49) ${ }^{1}$

The empty life tends to be accompanied by a sense of nihilism, which poses danger on those who would not be able to conquer and survive such moments. The appeal to death might lie in everyday moments.

Dickinson's pain and sorrow are bordering on a certain psychotic chaos. The consequent sense of loss and estrangement is manifest in her works. Under the pressure of the menacing sorrow, suicide becomes the best escape from the reality:

Escape is such a thankful Word

I often in the Night

Consider it unto myself

No spectacle in sight.

While it is intangible, the escape can relieve one of his/her pain substantially once it's done, and makes one "Feel easy" (J853). While dwelling on the affairs between Austin Dickinson and Mabel Loomis Todd in This Brief Tragedy: Unraveling the Todd-Dickinson Affair, John Evangelist Walsh incidentally reveals the speculation that Emily Dickinson might have attempted to commit suicide by taking strychnine.

\section{Conclusions}

Even though not so actively suicidal as Anne Sexon (1928-1974) and Sylvia Plath (1932-1963) in the following

\footnotetext{
${ }^{1}$ Prose Fragment 49, included on p.919 of The Letters of Emily Dickinson (Vol.3).
}

century, Dickinson is preoccupied with death and manifests her lust for death in her intensely reclusive life, which is considered suicide of a different category, as observed by Susan Kavaler-Adler: "Others, such as Camille Claudel, Emily Dickinson, and Emily Bronte withdraw into modes of seclusion from the world that result in a living death that is a form of emotional suicide"(43).

If she fails to realize her "suicidal wishes" literally, Dickinson suffers great pain in her "emotional suicide." Pain is a key word in Dickinson's poems, whether manifested or hidden: "Dickinson specializes in pain and suffering as the minute particulars of existence, and not as merely philosophical concepts" (Inder Kher 234).

However, pain also makes an important source for Dickinson's poetic creation, as John Cody notes, "What motivation to write could have replaced the incentive given by suffering and loneliness?" (495). During the course of fighting this negative experience, Dickinson has come to consider pain a necessity of life, and further transformed it into a positive force in her life and works: "I had a terror since September - I could tell to none - and so I sing, as the Boy does by the Burying Ground - because I am afraid -" (L.261). Dickinson, in her confrontation with pain and terror, develops her own solution: take "mirth" as "the Mail of Anguish" (J165), and learn to accept the existence of pain: "I like a look of Agony/ Because I know it's true -” (241).

\section{REFERENCES}

[1] Millicent Todd Bingham, Emily Dickinson's Home. New York: Harper \& Brothers Publishers, 1955.

[2] Cody, John. After Great Pain:The Inner Life of Emily Dickinson. Cambridge, Massachusetts: The Belknap Press of Harvard University Press, 1971.

[3] Gelpi, Albert. Emily Dickinson: The Mind of the Poet. Cambridge: Harvard University Press, 1965.

[4] Johnson, Thomas H. ed. The Complete Poems of Emily Dickinson. Boston and Toronto: Little, Brown and Company, 1960 .

[5] --- and Theodora Ward, eds. The Letters of Emily Dickinson. Massachusetts and England: The Belknap Press of Harvard University Press, 1979.

[6] Kavaler-Adler, Susan. The Creative Mystique, from Red Shoes Frenzy to Love and Creativity. New York: Routledge, 1996.

[7] Kher, Inder Nath. The Landscape of Absence. New Haven and London: Yale University Press, 1974.

[8] Leiter, Sharon. Critical Companion to Emily Dickinson: A Literary Reference to Her Life and Work. New York: Facts on File Inc., 2007.

[9] Leyda, Jay. The Years and Hours of Emily Dickinson. New York: Archon Books, 1970.

[10] Lowell, Amy. Poetry and Poets: Essays. New York: Noble 
Offset Printers, INC., 1971.

[11] Monroe, Russell R. Creative Brainstorms: The Relationship Between Madness and Genius. New York: Irvington Publishers, Inc., 1992.

[12] Porter, David T. Dickinson: The Modern Idiom. Cambridge, Mass.: Harvard University Press, 1981.

[13] Sewall, Richard Benson. ed. The Lyman Letters: New Light on Emily Dickinson and Her Family. Amherst: University of Massachusetts Press, 1965.

[14] Walsh, John Evangelist. This Brief Tragedy: Unraveling the Todd-Dickinson Affair. New York: Grove Weidenfeld, 1991.

[15] Wilbur, Richard. "Sumptuous Destitution." Emily Dickinson. ed. Bloom, Harold. Pennsylvania: Chelsea House Publications, 2007. 